This report wos prepared es an account of work sponsored by an agency of the United States UCID -20448 Government. Neither the United States Governiment dot any agency thereof, ner any of their employees, makes any wasranty, express of impliad, or assumes any legat liability of responsibility for the accuracy, completeocs, or uefuliess of any information, apperstus, produch, or process disclosed, or represents that its use would not infringe privately owned rights. Reference harein to any specific commercial product, process, or service by isade name, trademark, manufacturr., or otherwise does not necessarily constitute or imply its endorsement, recommendation, or favoring by tse United States Government or any agency thereor. The views and opisions of authors expressed herein do not necssarily stale or reflect those of the United States Government of any agency thereof.

\title{
Science, Technology, and the Industrialization of Laser-Driven Processes
}

\author{
James I. Davis \\ Jeffrey A. Paisner \\ May, 1985
}






\section{SCIENCE, TECHNULOGY, AND THE \\ INDUSTRIALIZATION OF LASER-DRIVEN PROCESSES}

\section{Introduction}

About 12 years ago, the laser program at Lawrence Livermore National Laboratory (LLNL) was given the charter to examine the potential use of lasers in industry for materials processing: in particular, to investigate those processes that could exploit the unique spectral, temporal, and spatial properties of leser light. One of the constraints implicit in this exercise was to focus on processes that were economically viable, i.e., ones that could generate support for the research and developinent of the laser and electro-optics technology. Our initial estimate was that it would take an investment of several hundred million dollars to accomplish this mission--to provide a reliable industrially hardened laser technology base.

\section{Candidate Elements}

Members of the laser program at LLNL reviewed potential applications of lasers in industry, some of which are listed in Fig. 1. Many of these areas are currently under active study in the community. We quickly focused on laser isotope separation of atomic uranium because of the large demand (>1000 tonnes/year) and high product enrichment price ( $\$ 600 / \mathrm{kg}$ of product) for material used as fuel in comerclal light-water nuclear power reactors.

We also belleved that once the technology was fully developed and deployed, it could be applled directly to separating many elements economically on an industrial scale. Figure 2 shows the elements whose electronic transitions are accessible using the fundamental and harmonics of the dye laser system under development at LUNL.

Some of the candidate elements are shown in Fig. 3. The Atomic Vapor Laser Isotope Separation (AVLIS) program at LLNL has an extensive uranium and plutonium program of $>\$ 100 \mathrm{M}$ in FY85 and a minor research program for other elements. 


\begin{tabular}{|c|c|}
\hline Application & Economic Potential \\
\hline - Isotope separation & $\begin{array}{l}\text { - Demands today a high value product } \\
\geqslant \$ 10 / \mathrm{kg}\end{array}$ \\
\hline - Cleanup of radinactive waste & $\begin{array}{l}\text { - Exiremely high payoff if, and only if, } \\
\text { a fully integrated reprocessing cycle is } \\
\text { realized, including military } \\
\text { applications. }\end{array}$ \\
\hline - Trace impurity removal & $\begin{array}{l}\text { - Cannot alone support technology de- } \\
\text { velopment but will be major spin off }\end{array}$ \\
\hline - Selective chemical reactions & $\begin{array}{l}\text { - Demands net gain in reaction (no. } \\
\text { particles/no. photons) }>1\end{array}$ \\
\hline $\begin{array}{l}\text { Photochemical activation or dissociation } \\
\text { of gases }\end{array}$ & $\begin{array}{l}\text { Potential high leverage in many } \\
\text { applications \{e.g., reactive etching, } \\
\text { coatings\} }\end{array}$ \\
\hline - Control of combustion particulates & $\begin{array}{l}\text { Will probably happen slowly as a spin } \\
\text { off }\end{array}$ \\
\hline - Crystal and powder chemistry & - Unique and interesting \\
\hline - Laser induced biochemistry & $\begin{array}{l}\text { - Inevitable but a decade at least before } \\
\text { some clarification }\end{array}$ \\
\hline
\end{tabular}

Fig. 1 Some potentlal applications of lasers in industry.

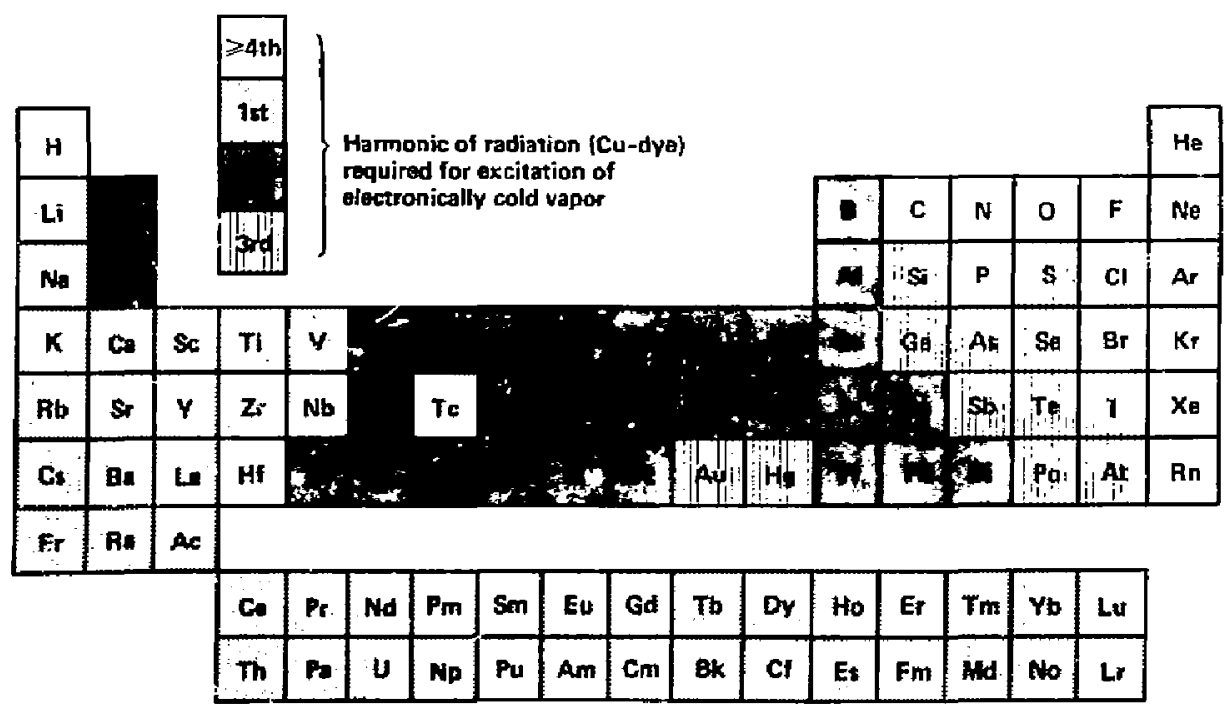

Fig. 2 Elements separable by AVLIS using copper-vapor (Cu)/dye lasor technology. 
Separative Woxk Units

Figures 4 and $S$ focus on the figures of merit for laser-driven processes. Here $S$ is the entropy of mixing $\Delta S$ expressed in terms of the constituent mole fractions $x_{a}, x_{b}, \ldots$ and normalized by the product of Boltzmann's constant $k$ and the total number of particles $N$. The terminology used jerives from the uranium-enrichment industry but is universally applicable to any chemical process. The productivity of a production module is given in terms of separative work units (SWUS). A thermodynamicist would recognize that separative work is just the difference between the Gibbs free energy of the product plus waste (talls) material, and the feed material. The relationships are fundamental and express the amount of work that must be employed to overcome the entropy of mixing or to alter the chemical potentlals of the components of the system. Actually the SWU is normalized in mass units. Value is given to both the product and talls material. The importance of this will be seen later.

Figure 5 introduces a simple economics model for laser-driven processes. The numerator contains the materials-handling cost and laser-related costs per $\mathrm{kg}$ of feed. The costs are derived primarily from engineering considerations. Laser energy is expensive, three to four orders of magnitude more expensive than erergy derived directly from oil or electricity. To establish the cost of the process, given in terms of \$/SwU, the numerator must be divided by the intrinsic separative performance of the process, given in dimensionless units of swu/kg feed. It is important to realize that separative performance is solely dependent on the process physics and plays an obvious role of process cost multiplier. Laser-related costs can be estimated as shown and depend sensitively on the photoselectivity of the process. Using the analysis for Uranium AvLIS, the total laser-related processing costs can be less than $\$ 10 / \mathrm{kg}$ feed.

As summarized in Fig. 6, separative performarce depends on the assays of both the product and tails material. Consequently, high SWU/kg feed can be achieved by depleting tails. Thus high selectivity is not essential for high separative work. However, as seen from Fig. 5, high photoselectivity is essentlal to achieve low MJ/kg feed and low \$/SWU. All else being equal, 


\begin{tabular}{|l|l|l|}
\hline \multicolumn{1}{|c|}{ Element } & \multicolumn{1}{|c|}{ Application } & \multicolumn{1}{|c|}{$\begin{array}{l}\text { Demand } \\
(\mathrm{MT} / \mathrm{y})\end{array}$} \\
\hline Uranium & Low-cost fuel for light water reactors & $>1000$ \\
\hline Plutonium & $\begin{array}{l}\text { Low-cost flexible purificatıon for } \\
\text { defense applications }\end{array}$ & $>1$ \\
\hline $\begin{array}{l}\text { Samarium } \\
\text { Europium } \\
\text { Gadolinium, etc. }\end{array}$ & Burnable poison for power reactors & $>1$ \\
\hline Mercury & More efficient fluorescent lamps & $>1$ \\
\hline $\begin{array}{l}\text { Zirconium } \\
\text { Titanium }\end{array}$ & Cladding for nuclear fuel elements & $>1$ \\
\hline $\begin{array}{l}\text { Rhodium } \\
\text { Palladium } \\
\text { Platinum }\end{array}$ & $\begin{array}{l}\text { Precious metal recovery from } \\
\text { nuclear waste }\end{array}$ & $>1$ \\
\hline
\end{tabular}

Fig. 3 Candidate elements for processing using atomic vapor laser isotope separation.

- The entropy of mixing in an ideal mixture

$$
s=x_{a} \ln x_{a}+x_{b} \ln x_{b}+\cdots,\left(s=-\frac{\Delta S}{k N}\right)
$$

- The "value" of a mixture is given by the function, $\psi$ :

$$
\psi=x_{a} \frac{\partial s}{\partial x_{a}}+x_{b} \frac{\partial s}{\partial X_{b}}+\cdots
$$

- The net "value" of a separation process is given by, $\Psi$ :

$$
W_{f} \Psi=W_{p} \psi_{p}+W_{t} \psi_{t} \cdot W_{f} \psi_{f},(W \text { in kilograms })
$$

- This nomenclature has led to the following terminology:

$$
\begin{aligned}
W_{f} \Psi & \triangleq \text { SWUs, separative work units } \\
\Psi & =\frac{S W U}{W_{f}}, \text { dimensionless measure of process work }
\end{aligned}
$$

Fig. 4 Definition of separative work in discrete processes. 
Process engineering costs

Material handling subsystems

Laser electro-optic subsystems

$\$ / S W U=\frac{\left(S / \mathrm{kg}_{\mathrm{F}}\right)_{\mathrm{M}}+(\mathrm{S} / \mathrm{MJ})_{L}\left(\mathrm{MJ} / \mathrm{kg}_{\mathrm{F}}\right)}{S W U / \mathrm{kg}_{\mathrm{F}}}-\begin{gathered}\text { Process performance } \\ \text { Laser vapor interaction }\end{gathered}$

- $\$ \$ / M J\rangle_{L} \sim \$ 1-100$

- $\left(\mathrm{MJ} / \mathrm{kg}_{\mathrm{F}}\right) \sim \frac{1}{E} \times \frac{\mathrm{h} \nu(\mathrm{eV})}{\text { particle }} \times 1.6 \times 10^{-16} \frac{\mathrm{MJ}}{\mathrm{QV}} \times 6 \times 10^{23} \frac{\text { particles }}{\text { mole }} \times \frac{\mathrm{X}_{\mathrm{F}} \text { moles }}{\mathrm{M}(\mathrm{kg})} \times\left[1+\frac{1}{\mathrm{~S}} \frac{\left(1-\mathrm{X}_{\mathrm{F}}\right)}{\mathrm{X}_{\mathrm{F}}}\right]$

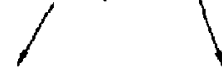

Utilization Photon energy

Mole fraction of excited material 1 mole feed

Photo-selectivity

$\left(M J / k g_{F}\right) \sim 10 \times X_{F} \times\left[1+\frac{1}{S} \frac{\left(1-X_{F}\right)}{X_{F}}\right] \sim 10^{-1}$ for uranium AVLIS

Fig. 5 Elementary economics model.

- High selectivity is not essential to achieve high $\mathrm{SWU} / \mathrm{kg}_{\mathrm{F}}$

- High selectivity is essential to achieve low $\mathrm{MJ} / \mathrm{kg}_{\mathrm{F}}$ and low $\$ /$ SWU

- AVLIS process has very high process photo-selectivity

Fig. 6 Photo-selectivity for a laser-driven separation process. 
a process that has low feed assay $X_{F}$ and low selectivity $s$ will have a laser cost $1 /\left(s \cdot x_{F}\right)$ times higher than a process with high photoselectivity. As an example, a Lranium LIS process with a photoselectivity of 2 w1ll require 70 times higher $\mathrm{MJ} / \mathrm{kg}$ feed and have a concomitantly higher laser-related cost of $>\$ 100 / \mathrm{kg}$ feed. This is one of the reasons we chose the AVLIS process since it can achieve extremely high process photoselectivity, as shown in Fig. 7 .

\section{Spectroscopic Selectivity}

The approach being used at LLNL is a three-step photoionization process that exploits the large isotope shifts in the electronic spectrum of atonic uranium. These isotope shifts derive primarily from nuclear volume effects. Since the ionization limit is about $6 \mathrm{eV}$, a three-step pricess Involves lasers operating at about $2 \mathrm{eV}$ or $6000 \mathrm{~A}$. Consequently, we use pulsed dye lasers pumped by copper-vapor lasers in the process. Very high photoselectivity is attained on each step. The net photoselectivity in the process is extremely high as indicated. The photoionization process can be described as an optical distillation column where work is done only on the isotope or specie of interest.

\section{Major Systems}

The major systems that comprise a mudule in the AVLIS process are shown in Fig. 8. Uranium is vaporized by a high-valtage electron beam from a cruchle containing the metal. The uranium in the melt is heated to tempejatures in excess of $3500 \mathrm{~K}$. The vapor-pressure gradjents established above the melt are sufficlent to cause aerodynamic expansion of the vapor flow. The direct flow is then irradiated transversely by the photoionizing lasers. The pulse-repetition rate of the laser is sufficiently high to ensure that all the vapor is irradiated. The copper-vapor lasers are configured in sets of master oscillator/power amplifier (MOPA) chains, each operating at about $5 \mathrm{kHz}$. The dye lasers are also configured in MOPA chains. The ${ }^{235} \mathrm{u}$ photoions are extracted by a combination of 




Sharp electronic spectrum and moderate state density

Large spectroscopic selectivity and

large absorption cross sections

F1g. 7 Spectroscopic selectivity - AVLIS.

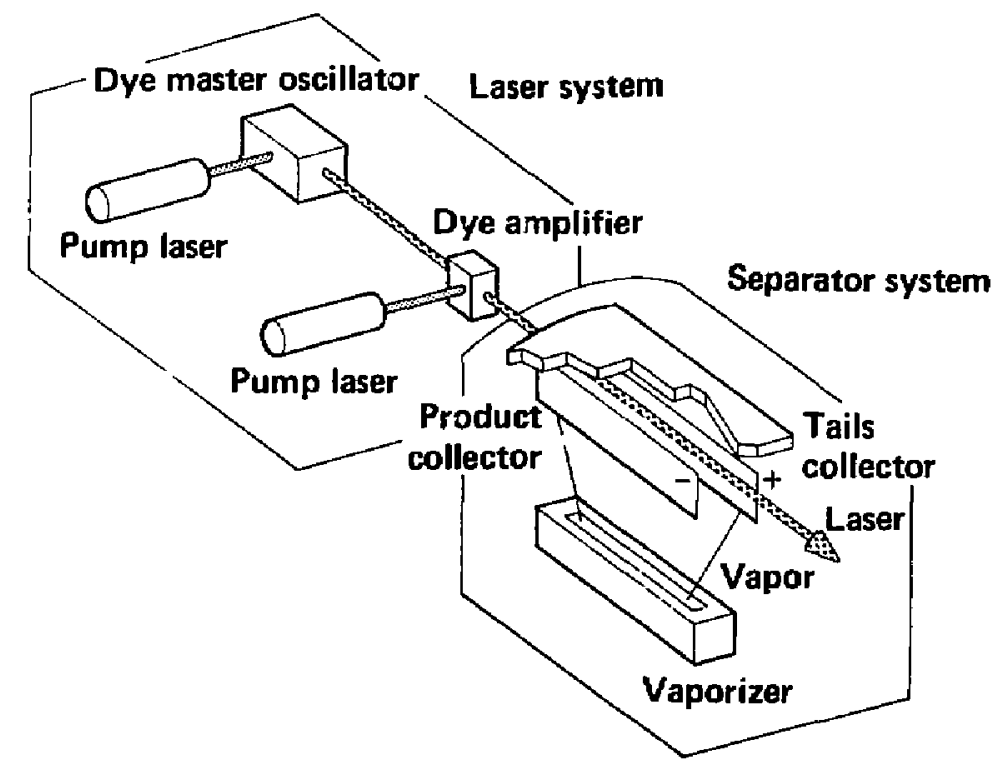

Fig. B Atomic vapor laser isotope separation - major systems. 
electric and magnetic flelds and collected on product plates. The remaining vapor depleted in ${ }^{235} \mathrm{U}$ flows to the tails collector. The assay of the talls material depends on the fraction of ${ }^{235} \mathrm{U}$ ionized and collected. The assay of the product depends not only on this quantity but also on the fraction of the feed macerial that deposits nonselectively on the product plates. A major feature of the AVLIS process is that both product and tails material are collected as liquids and are allowed to flow to collection pots. This aspect of the design has been developed by Martin Marietta Energy Systems in Dak Ridge, TN, who are an integral part of the AVLIS program.

It takes about 1 swu/kg feed to achleve the enrichment needed to obtain material for light-water reactors ( $0.7 \%$ feed to $3.2 \%$ product) as shown in Fig. 9. The exact separative performance depends on the tails assay considered and is pretty much independent of product assay. The tails assay is a design specification depending on the relative costs for separative work ( $\$ / S W U)$ and reed costs. The gaseous diffusion plants operate at a tails assay to make enrichment costs ( $\$ 600 / \mathrm{kg}$ product) about equal to feed costs ( $\$ 600 / \mathrm{kg}$ product). The AVLIS process is capable of achieving high separative work (1 SWls/kg feed), the required product assay, and very low tails assay in very few stages. Consequently, the laser-related separative work costs can be less than $\$ 20 / \mathrm{SWU}$, or less than $\$ 100 / \mathrm{kg}$ product and the feed costs can be significantly reduced.

\section{Facilities}

It has taken about 10 years ior the Aulis program to reach its current state of maturity. Figure 10 summarizes the uranium AVLIS program. We are presently in a production-scale systems-integration stage, having completed process science studies and developed and tested the laser and separator subsystems in stand-alone as well as in fully integrated enrichment operatioris.

Figure 11 illustrates the layout of the full-scale demonstration facllity that has just been activated at LLNL. The building houses a uranium separator module called the separator demonstration facility. The 


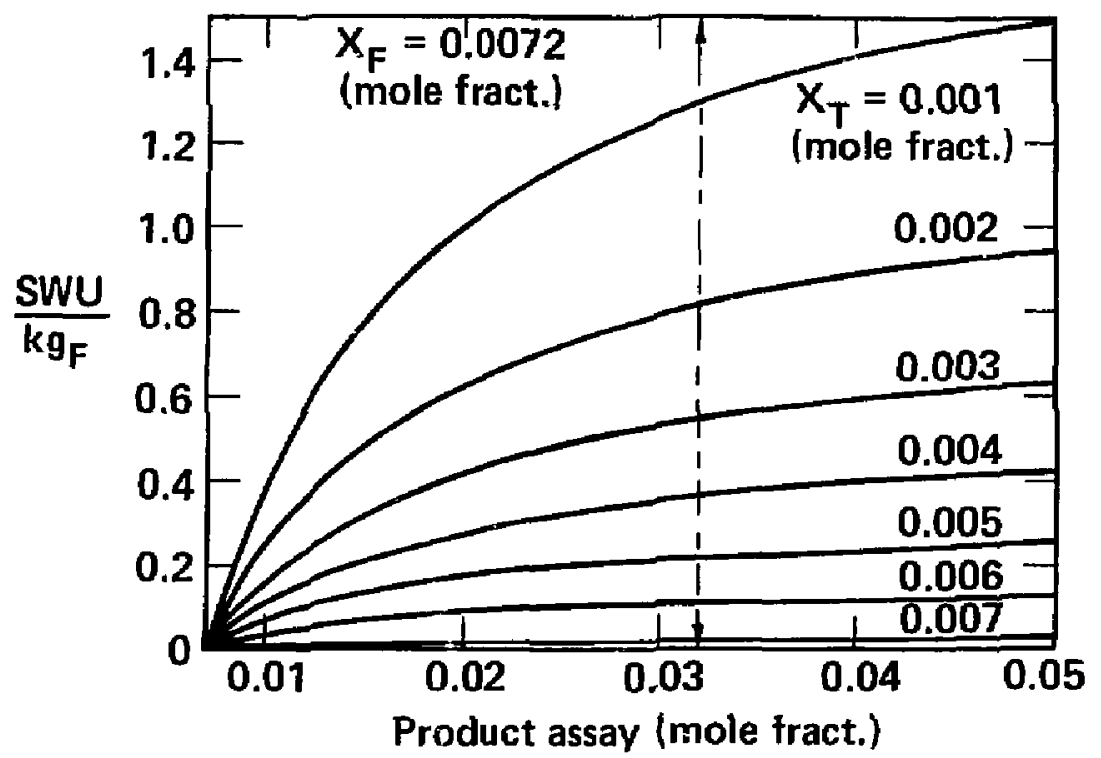

Fig. 9 Separative performance map for uranium enrichment.

- Process science (1974-1980)

- Functional systems integration (1978-1985)

- Production systems integration (1984-1990)

- Economic production operation in 1990s

Fig. 10 Uranium AVLIS program - summary. 
bullding also contains a laser system called the laser demonstration facllity that will provide the laser power for the module. The balance of the building contains instrumentation and control systems and refurbishment facilities in support of the laser and separator systems.

Figure 12 is an aerial photograph of the facility taken a few months ago. The octagonal structures on the left are the office buildings that house the program scientists, engineers, and administration staff at LINL.

Figure 13 is a photagraph of the first completed corridor of cmper-vapor MOPA chains installed in the facility this April. There are 6 MOPA chains containing 30 laser heads with a total output capability of several thousand watts.

Figure 14 shows the separator module in the full-scale demonstration facility. The tanks at the ends house the module optics for directing the laser beams through the uranium vapor. The module is essentially plant size and has a projected production rate of about $1 \times 10^{6}$ swu/year, or $2 \times$ $10^{5} \mathrm{~kg}$ product/year.

For the past several years, we have transported the output of the laser subsystems over long df.stances ( $\sim \mathrm{km}$ ) to separator subsystems located in uther buildings. Figure 15 shows an aerial view outlining the path of this optical-transport system. The distance between the laser demonstration facility and our special-materials testing facility is about $2 \mathrm{~km}$, while that to our half-scale uranium separator is over $1 \mathrm{kli}$.

Using the initial increment of light available from our new laser facillty, we have recently conducted integrated enrichment demonstrations in our half-scale facility (FIg. 16). This facility has been operational for several years.

\section{Integrated Process Model}

Returning to same of the concepts introduced in the beginning of this report, we have proceeded to the presert generation of systems after intensive study of the interplay of the physics and engineering that govern the AVLIS process. Figure 17 shuws schematically some of these areas and how they influence process design and cost using the simple economics 


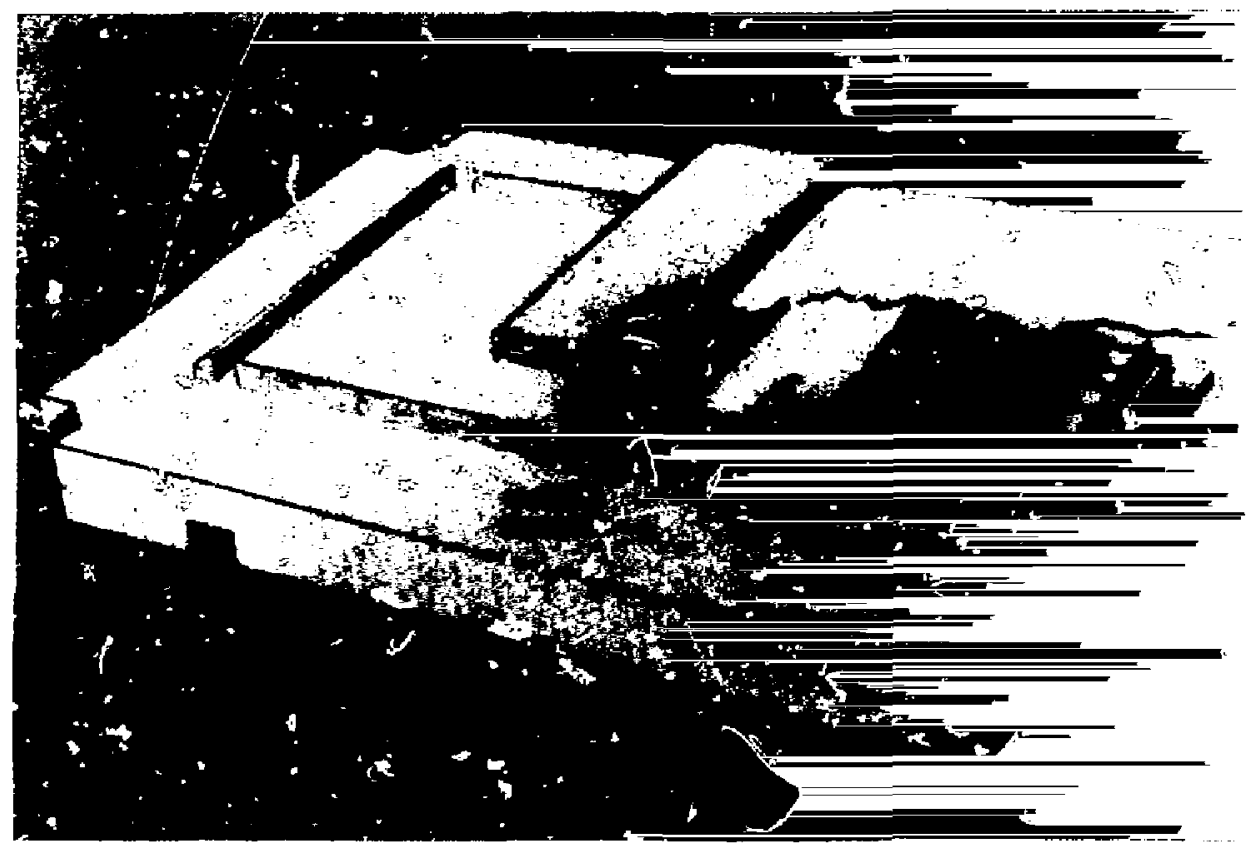

F1g. 11 Production-scale AVLIS demonstration system.



Fig. 12 Full-scale demonstration facility at LLNL (Feb. 1985). 


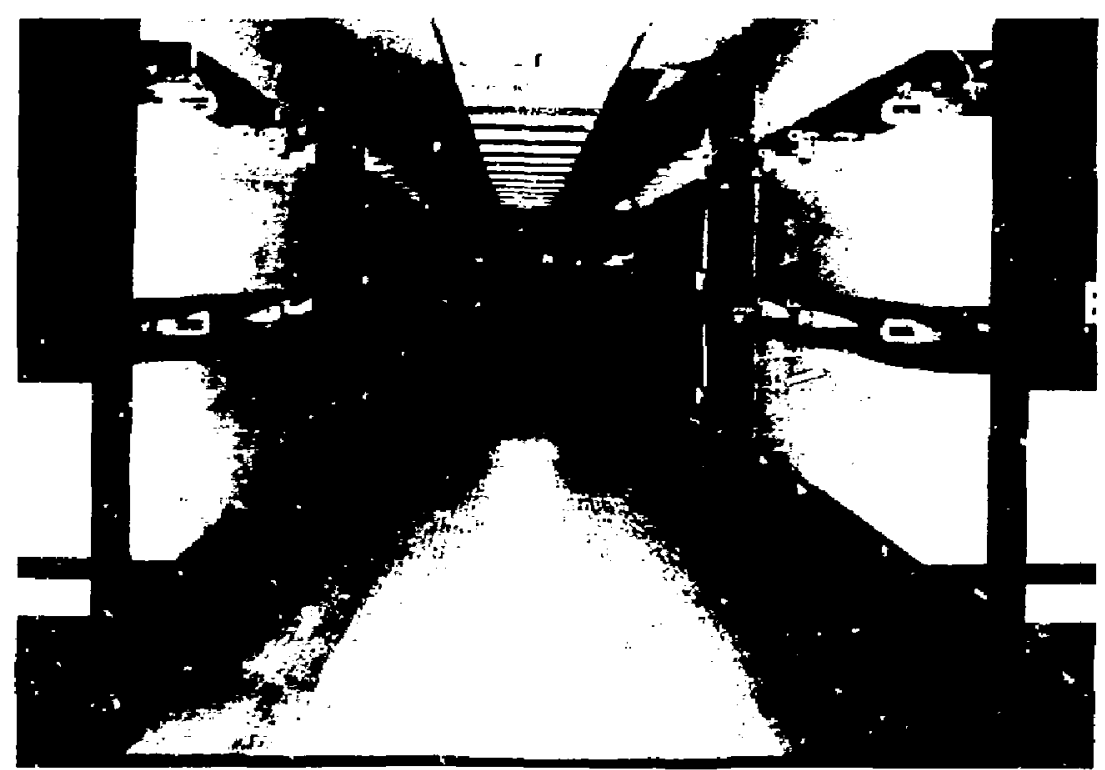

Fig. 13 Full-scale demonstration facility copper-vapor laser system (April 1985).



Fig. 14 Full-scale demonstration facility separator module (April 1985). 


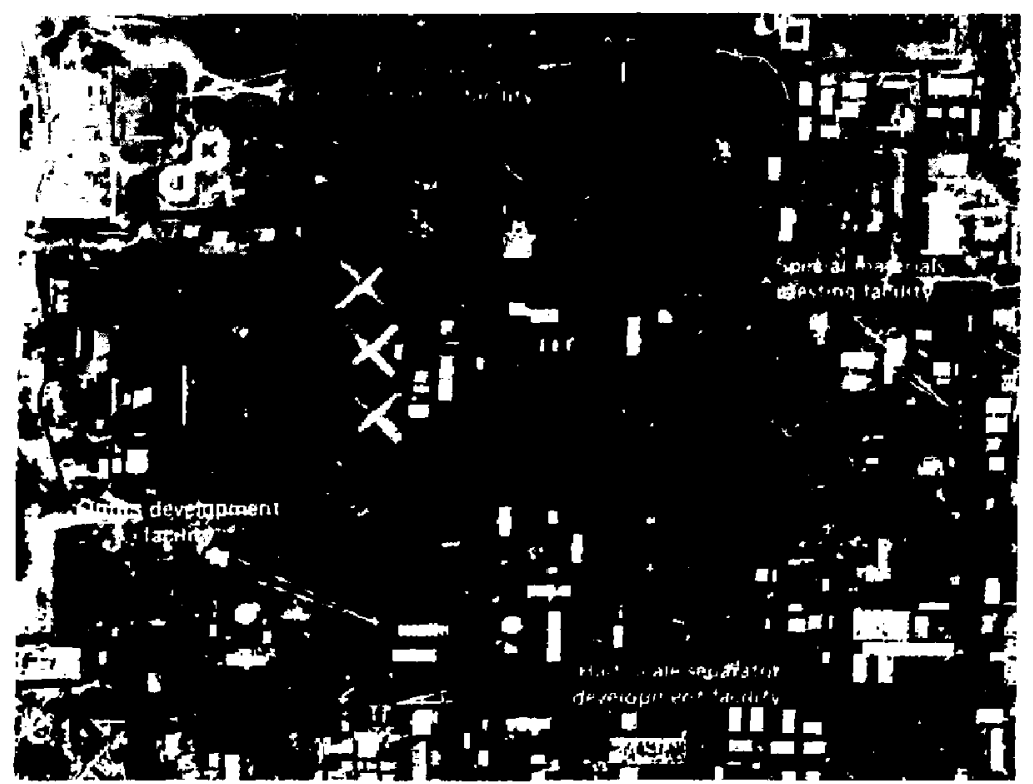

Fig. 15 Beam tube for optical transport between facilities at LLNL.

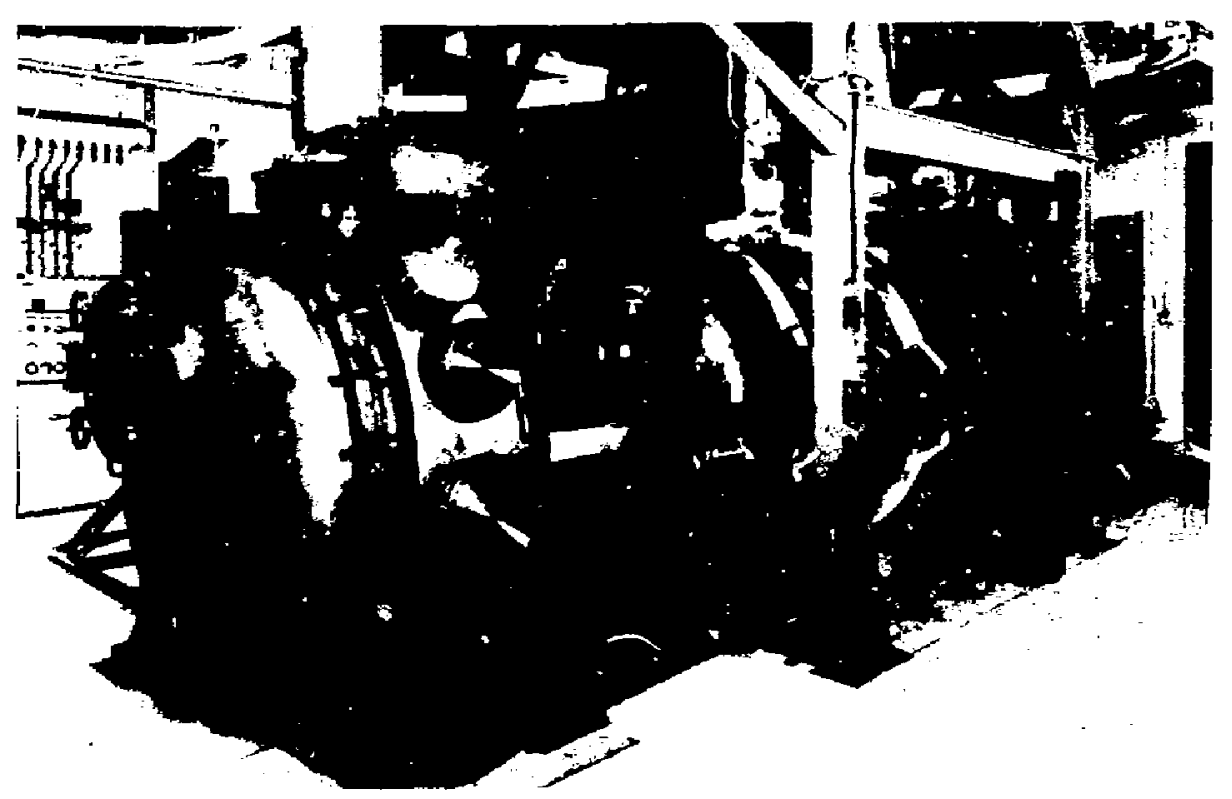

Fig. 16 Half-scale separator at LLNL. 
construction show earlier. Eacli physics area has been modeled, in some cases from first principles, and benchmarked against rasults obtained in the laboratory or in systems such as the half-scale separator.

Figure 18 shows an example of the detailed modeling that we do in the area of photolonization and propagation physics. Gne of the novel features of the process and of the laser system is that we can specify and control the spectral content of the tunable dye lasers to optimize overall photoionization performance.

We have incorporated these physics models along with engineering models in an integrated process model (Fis. 19). The engineering cost models Include results from detailed bottom-up costing studies and data obtained from procurements for the full-scale demonstration facility. We also include in the process model operational parameters based on reliability, availabllity, and maintalnability of AVLIS subsystems. Essentially, the integrated process model contalns all the fine detail of the AVLIS process and allows us to examine the sensitivity of cost and performance tc variation in englneering, design, and physics parameters. We use he code to guide process design. The code 15 also used to quantify the injpact of uncertainties in process parameters, which range from tite values for the optical-transition cross sections to the cost of labor. The code was originally constructed by the staff at Martin Marietta Energy Systems to perform multivariabie sensitivity studies.

\section{Multivariable Sensitivity Studies}

There are literally hundreds of parameters that affect the cost of the process. Each one of these parameters has an associated uncertainty and uncertainty distribution (Fig. 20). The cade is capable of using these distributions in a Monte Carlo calculation of performance and of comparing it to the performance using our base-case design values. In the example shown in Fig. 20, the parameter of interest may be the charge-exchange cross section. As our data base improves, the uncertainty assoclated with each of these parametars becomes smaller. 




F1g. 27 AVLIS process morphology/structure of integrated process model (IPM).

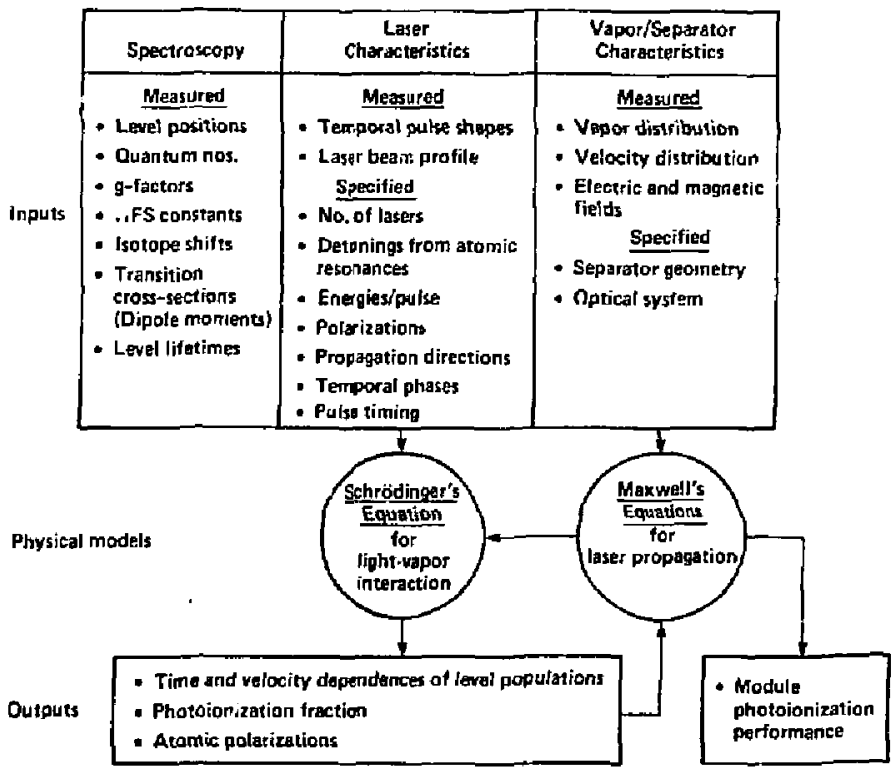

Fig. 18 Modeling of laser - atomic vapor interaction. 


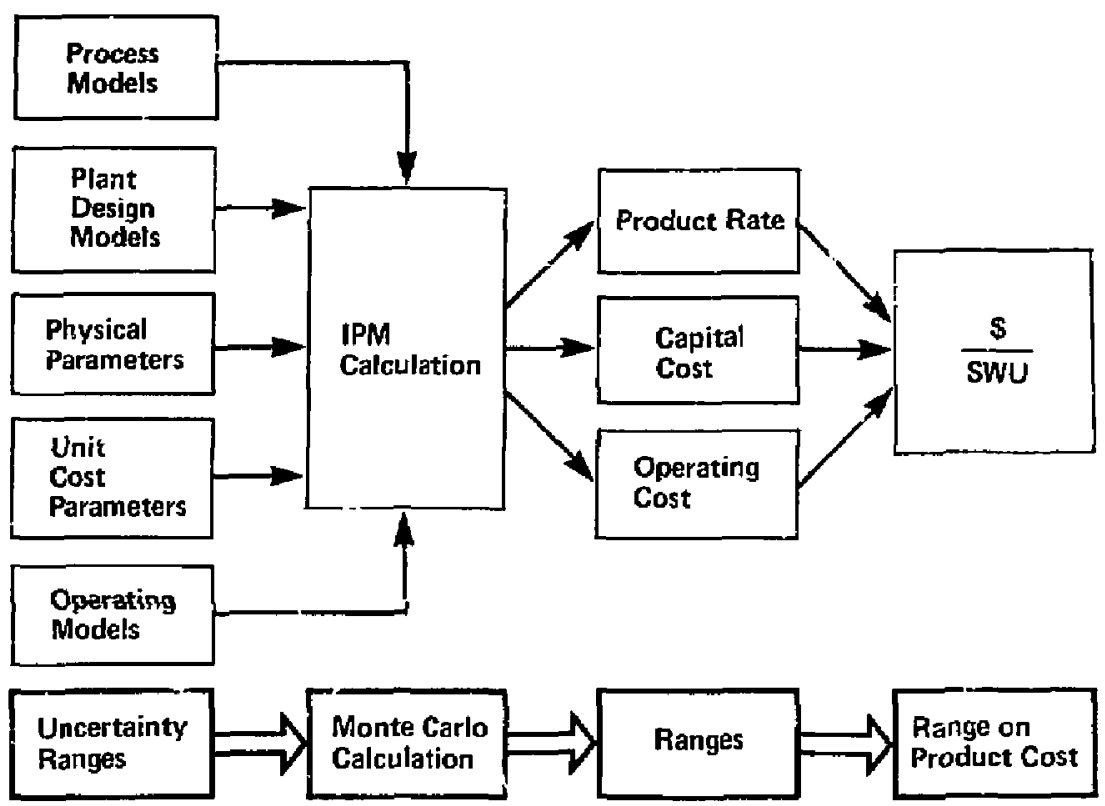

Flg. I9 Integrated process model and multivariable sensitivity studies.

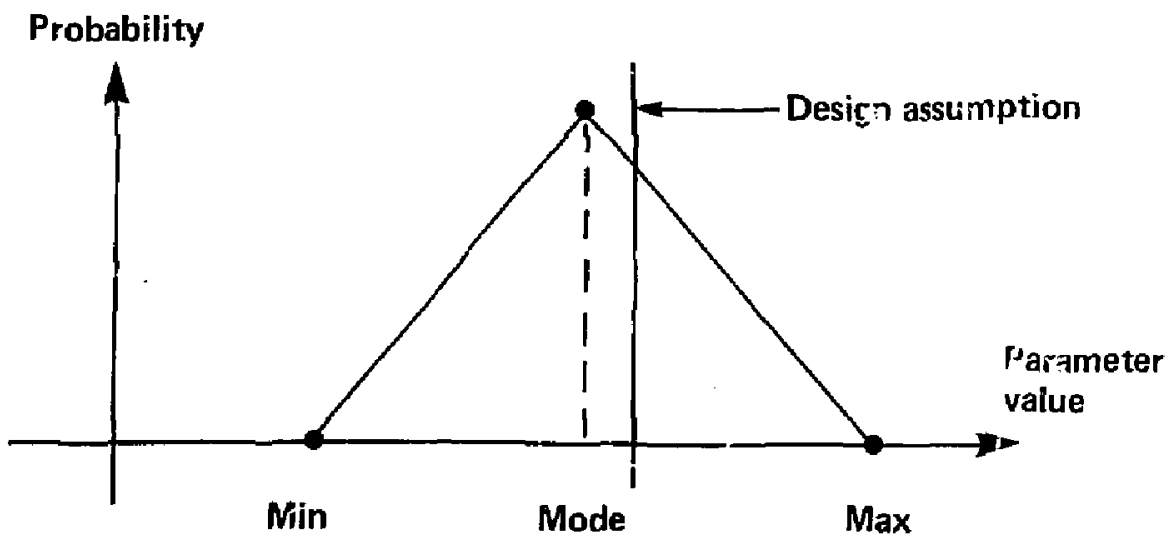

F1g. 20 Generic MVSS parameter description. 
Figure 21 is an MVSS histogran for process separative work cost fur the 1981 AVLIS engineering design.

\section{World Market}

Up to this point we have emphasized process economics. To industrialize any process one must also be cognizant of market economics. Flyure 22 sumarizes the present market conditions for enriched uranium: prices are expected to drop. This results in part from world enrichment capability presently exceeding demand and the presence of a world inventory of several years' demand. A new technology for the U.S. enrichment enterprise is only attractive if its total cost is below the operating costs of existing capacity.

\section{U.S. Enrichment Enterprise}

Presently, there are two advanced technolngies in the U.S. being considered for potential production: the Advanced Gas Centrifuge (AGC) and AVLIS (Fig. 23). Both of these programs are funded out of net revenues from sales of enriched materlal from the gaseous diffusion plant (GDPs). Although the profits from the GDPs are in the hundreds of millions of dollars, in order to ensure that the U.S. ramains competitive in the world market in the future and achieves its target prices, the Department of Energy accelerated the selection date for an advanced technology to 1985 . During the past year, the AVLIS program has been under intense technical scrutiny by our peers in the AGC program and by a process evaluation board. The board reports directly to the Secretary of Energy whose decision is imininent.

\section{Sumary}

As a final note, dozens of scientists, engineers, and supporting staff have comitted over a decade of their lives in trying to bring this technology to Industrial scale. If AVLIS is chosen, we hope the rest of the laser and electro-optics comunity will share in the excitement arit challenge this wi!l offer for the future of laser-driven processes. 




Fig. 21 AVLIS MVSS results: distribution of projected separative work cost -9 million swu/y (1981 design, 1982 dollars).

- Prices expected to drop

- World separative work capacity presently exceeds demand

- World inventory of several years demand exists

- DOE has set target prices that will keep the enterprise compatitive

- Replacemen i capacity with new enrichment technology is attractive if its total cost is below the operating costs of exiscing capacity

Fig. 22 World market for uranlum enrichment. 




Fig. 23 Structure of U.S. enrichment enterprise. 
CONTENTS

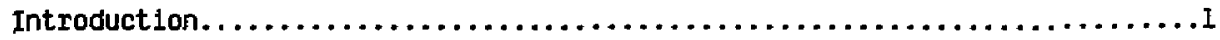

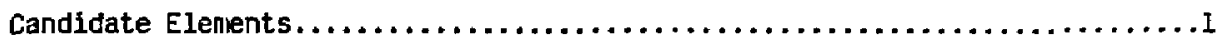

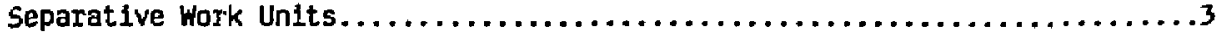

Spectroscopic Selectivity..............................6

Major Systems........................................



Integrated Process Model. ..................................10

Multivariable Sensitivity Studies.............................. 14

World Market.................................................

U.S. Enrichmant Enterprise.................................

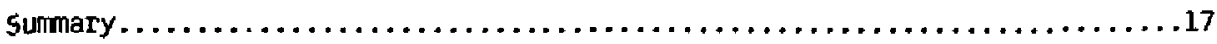

itiliv 